\title{
Limits of Critical Theory, Critique and Emancipation in Habermas' Critique of Horkheimer and Adorno
}

\author{
Fasil Merawi \\ Addis Ababa University, Faculty of Social Sciences \\ Department of Philosophy
}

Received 8 November 2018 - Revised 25 December 2018 • Accepted 26 December 2018

\begin{abstract}
Habermas' critical theory is partly an attempt to identify the limitations of critique and emancipation as espoused in the first generation critical theory of Max Horkheimer and Theodor Adorno. In their attempt to develop an interdisciplinary, reflexive, emancipatory and dialectical reason that is critical towards accepted realities, Horkheimer and Adorno in their monumental work The Dialectic of Enlightenment pictured a world trapped in instrumental rationality. Taking and revolutionizing traditional critical theory, Habermas argues that reason entails both emancipator as well as instrumental possibilities. Through an exposition of Habermas' critique of Horkheimer and Adorno in his discourse of modernity, this article argues that although Habermas successfully identifies the equation of the rational with the instrumental and offers an emancipator model in return; still he ends up not paying sufficient attention to aesthetic truth.
\end{abstract}

Keywords: enlightenment, myth, communicative reason.

\section{Introduction}

The philosophy of Habermas involves a general venture into the contradictions of the modern world which in its emancipatory intent to realize linguistic validation came to be interspersed with the fate of instrumental reason. As such, working under the guiding spirit of the critical theories of Horkheimer and Adorno that any serious intellectual form of discourse must enclose both deconstructive and emancipatory elements, Habermas introduces his own unique communicative paradigm. Here resisting the equation of the rational with the instrumental as developed in the monumental The Dialectic of Enlightenment; Habermas introduces a reconstructive process that strengthens everyday communicative action. The discussion on this article focuses on Habermas' critique of Horkheimer and Adorno's critical theory in his The Philosophical Discourse of Modernity.

In section one, I try to expose Habermas' discussion of Hegel as a way of uncovering the guiding spirit of the modern age as subjective freedom. Such optimism soon encounters a rebuttal in Nietzsche's radical critique of reason. Section two shows how according to Habermas' views on the fate of critical theory, Nietzschean critique soon branches out into Horkheimer's equation of the rational with the oppressive. After I summarized Habermas' picture of modernity in section three, finally, I use David Ingram's discussion to highlight the marginalization of the aesthetic in Habermas' discourse of the modern.

(C) Authors. Terms and conditions of Creative Commons Attribution 4.0 International (CC BY 4.0) apply. Correspondence: Fasil Merawi, Lecturer, Addis Ababa University, Faculty of Social Sciences, Department of Philosophy, Addis Ababa, ETHIOPIA. E-mail: fasil.merawi@aau.edu.et. 


\section{Modernity and subjective freedom}

Habermas' discourse of modernity heavily relies on Hegel's conception of freedom and subjectivity. Thus, Habermas asserts that the young Hegel, witnessing the cruelties of history and its tragedies first hand, postulated reason as a tool of unification and final harmony manifested in history's contradictions. As such, most philosophies of the Enlightenment focused on the limits of reason and of human cognition, and how understanding is possible based on the self-reflecting subject. Instead, Hegel focuses on an absolute reason that underlies both individuals and societies, and brings a final harmony. According to Habermas, the young Hegel with Schelling and Holderlin in the Tubingen seminary developed a concept of public religion that stood against the current religions, Enlightenment and its orientation towards religion. For Hegel, the concretely established religions of his day were based on authority, while the Enlightenment's out- look towards religion was abstract and ideal. Instead, Hegel opted for a religion carried out through public religious ceremonies, involving members of the society and creating bonds or solidarity between individuals. Hegel focused on a religion, which is to: "present itself in public in celebrations and cults, only if it connected up with myths and addressed the heart and the imagination, could it, as religiously mediated morality, "be woven into the entire fabric of state" (Habermas, 1987: 26). Hegel applied his critique of religion to current political structures of the day, which he saw as failing to bring a harmonious relation between the individual and the state and their laws being based on authority and divorced from the communal life.

In the essay Spirit of Christianity and its Fate, Hegel advocates a reason, manifesting itself in a public religion and unifying subjects. This is based on a community, where a reciprocal and symmetrical relation is established between members of society. For Hegel, this is the ethical and not the moral state. Hegel meant by "ethics" a conscious membership in society and reciprocal relations amongst enlightened individuals. While by "moral", what Hegel has in mind, is a community filled with egoistic rational individuals, each competing to satisfy their needs. (Melchert, 2002: 490). So, in opposition to abstract moral laws and rights, Hegel focused on reciprocity between members of a society and punishment of those who stand against the harmonious order. Besides religion, Hegel also advanced his ideas of unity and harmony in his views on art. Art was supposed to express the truths of religion in an ethical state. But, Hegel abandoned his aesthetic ideals, after realizing that the essence of modernity is reason, and the problem of modernity is its fragmentation into three spheres. So, what was needed is not an aesthetic union, but a reason that brings together the different spheres and contradictions of history and concrete life (Habermas, 1987: 31-32).

In place of Hegel's absolute, Habermas proposes his intersubjectivist approach to rationality. This constitutes, conceiving modernity in terms of the rationalization of the lifeworld i.e. abandoning of conventional standards and pre-modern religions, traditional outlooks. This resulted in the planting of different spheres i.e. theoretical, moral and aesthetic correlating to the everyday world and its three validity claims to objective social and subjective worlds. Thus, the focus is on the lifeworld, how speech acts coordinate our social actions through validity claims, and the continual production of truth in reciprocity. This differs from Hegel's philosophy of right which holds the state as the concrete actualization of the spirit in history (Ibid., 37-40). From Habermas's vantage point, Hegel's philosophy did not escape the limits of the philosophy of the subject. Reason is depicted as an overarching and overwhelming force behind the contradictions in actual history and also the various stages in the development of consciousness are devalued. So the current existing reality, which has a potential for critique is devalued, since it's held to be part of a greater whole, i.e. the progress of history towards absolute spirit. This also devalues intersubjectivity, since subjects are finite and small parts in the dialectical movement of history.

Hegel, on his essay On the Essence of Philosophical Criticism, elaborated two kinds of criticism. First, it's developed as a critique of degenerated, repressive current forms of life preventing progress. Secondly it emerges as a critique of subjective idealism within the 
philosophies of Kant and Fichte, which resulted in various dichotomies, and failed to show the unity of human experience. Hegel. In his Philosophy of Right only carries out a critique towards idealist philosophies and hence focuses less and less on critique of actuality. As Habermas claims, this; "blunting of critique corresponds to a devaluation of actuality, from which the servants of philosophy turn away" (Ibid., 43). Here Habermas elaborates on Schiller's Letters on the Aesthetic Education of Man to show how the idea of intersubjectivity was also presented through art. Habermas acknowledges Schiller for being the first to introduce an "aesthetic critique of modernity" (Ibid., 45). Schiller objected Greek poetry and art for appealing to authority of the gods and having a religious outlook. He also criticized bourgeoisie society for promoting an excessive individualism and selfishness, and also modern science which based on its abstract rules and logic negated everyday sensuous life. Instead: "Schilller stresses the communicative, communitybuilding and solidarity-giving force of art, which is to say, its public character" (Ibid., 46). Schilller's general focus was on the tension between the passionate and material on one hand and the capacity found in understanding and imposing order in man on the other. So, Schiller in his concept of the artistic beauty or the appearance, tried to postulate how the aesthetic, frees man from both sensuous nature and capacity for reason, and instead tries to mediate the two. So, art for Schiller; "arouses a middle disposition, in which our nature is constrained neither physical nor morally and yet is active both ways" (Ibid., 48).

According to Fred Dallmayr, Habermas's critique of Hegel's conception of modernity can be summarized by two points. Hegel tried overcoming the philosophy of the subject himself standing under or working under the premises of the philosophy of the subject and failing to project a reason that can unify humanity's experiences. Hegelian discourse on modernity also being very abstract leads to a devaluation of the actual. Hence, it's highly contemplative (Dallmayr, 1987: 688).

One of the things unique to Hegelian philosophy is the fusion of the "popular" and "academic" conceptions of philosophy. While Kant maintained a distinction between philosophy as it is conceptualized commonly and as it is practiced by intellectuals, Hegel succeeded in bringing and analyzing the current, existing condition in his own philosophy and hence abolishing the hitherto distinction between worldly and academic concept of philosophy. After Hegel's death, philosophy came to be practiced by academicians in institutions and universities theoretically, and amongst other things this resulted in philosophy, losing its connection with the everyday world, and the introduction and application of the various sciences to conceptualize and analyze the world. This changed for Habermas, in Heidegger's Being and Time, when Heidegger tried to lay out the everyday structures that ground "Dasein", and hence the use of philosophy in deciphering concrete structures. Also, the Hegelian Marxists using Weber's analysis of Marx tried to reestablish the link between philosophy and the concrete with a "theory of reification" and establish links between "economics and philosophy" (Habermas,1987: 53). Also from Husserl to Foucault, philosophy has tried to reestablish its link with the given, by way of a critique of the sciences.

Still, all these attempts are different from Hegel, since beyond trying to conceptualize current history in philosophical themes, Habermas sees in these various ventures, an advocacy of the end of philosophy discussions in different ways. The end of philosophy discussion is an attempt to put an end to philosophy as it is traditionally practiced and culminated in the current scene. Of course, there are diverse orientations here. For instance, in Heidegger traditional philosophy failed to reflect on being as such and instead focused on particular entities. In young Hegelians philosophy as practiced hitherto was meditative and hence needs to stay in touch with the particular and concrete. 
3. Nietzsche and the radical critique of reason

In Nietzschean philosophy, Dionysus represents the passionate tendencies in human beings. As a god it never arrives. So the tendencies it represents i.e. the passionate and emotional are realized in the space it leaves through artistic practices. The idea of Dionysus as the coming god who presents himself with absence was according to Habermas, also developed in early Romanticism. Accordingly, the idea of Dionysus was taken as an equivalent for Christ as the messiah who comes in the future and is currently absent (Habermas, 1987: 91). This absence creates a space in this world where the promises of the Enlightenment, and the infinite worth of individual, its interrogation of tradition and affirmation of its rights, will be realized. So, Nietzsche recognizes how Wagner takes up the romanticist theme of fulfillment in this world through absence, of the other-worldly, and thereby rejects the latter's approach. This is since, for Nietzsche all forms of other worldliness end up in a negation of this life and the degradation of it as fleeting, finite, and so on. Accordingly, "the mature Nietzsche recognizes that Wagner in whom modernity is almost 'summed up', shared with the romantics the perspective on the still to come fulfillment of the modern age" (Ibid., 92).

One of the things that Nietzsche maintained in his Birth of Tragedy is the Schopenhauerian insight that the principle of individuation has limitations. For Schopenhauer, going beyond Kant's identification of the noumenal as the "unknowable" one could attribute the noumenal world to the world of will. In the phenomenal world, the principle of individuation makes it possible for individuals to grasp the world by applying space and time. But, beyond this, the world of will manifests itself in the individual in form of excessive desires and inclinations, resulting in feeling of pain and suffering. Schopenhauer provided a disinterested art and contemplative life as an alternative. Later, Nietzsche rejected Schopenhauer's approach claiming that it denies the basic nature of life as will to power, or endless desire to impose meaning and order on things, and instead simply tries to affirm the pessimistic side of life (Love, 1986: 39). In his aesthetics, Nietzsche focuses, according to Habermas, on how the individual in the "aesthetic phenomenon", sets himself free from norms, conventions and values, and generally goes beyond cognition, language and reason (Habermas, 1987: 93).

One of the things that Nietzsche takes from the Romantics is the differentiation of the aesthetic from those of science, morality and other realms, and also an emphasis on how it steps outside the bounds of reason. This aesthetic ideal focuses on ancient Greek tragedy, the identification of the aesthetic with the non-rational and emphasis on how Dionysus brings in a passionate, fragmented, non-cognitive element to reality. Nietzsche for Habermas introduces a new kind of critique of modernity, one that tries to step outside of reason, in order to critique reason. Hence:

Subject-centered reason is confronted with reason's absolute other. And as a counterauthority to reason, Nietzsche appeals to experiences that are displaced back into the archaic realm-Experiences of self-disclosure of decentred subjectivity, liberated from all constraints of cognition and purposive activity, all imperatives of utility and morality (Ibid., 94).

What Nietzsche, would like to bring into the scene with his art is the value of life. How the world as a chaotic, non-theoretical realm of experience, witnessing both joy and suffering and resisting inclusion into a grand theory, original plan, or final goal, is to be deciphered through an oriented outlook towards the world.

\section{Horkheimer, Adorno and the dialectic of reason}

In Horkheimer and Adorno's critical theory, myth gains its identity standing in relation to enlightenment, and vice versa. The enlightenment's rise for Horkheimer and Adorno is related to a superseding and surpassing of mythic grounds. "Enlightenment has always taken the 
basic principle of myth to be anthropomorphism, the projection onto nature of the subjective. In this view, the supernatural spirits and demons, are mirror images of men who allow themselves to be frightened by natural phenomena" (Horkheimer \& Adorno, 1982: 6). By using Homer's odyssey, Horkheimer and Adorno tried to depict a subject who has managed to control the world but is at the same time at wars with himself. Odysseus tries to exercise theoretical and practical knowledge over the world by increasing his understanding of the environment and also by practically being able to control his surroundings. But the more he manages in controlling the world, the more he is depriving his nature. The basic ability of humans to relate to the world in general by experiencing it is replaced by an instrumental relation that tries to manipulate the world. So, "Odysseus's loss of pleasure in the world entails loss of experience of the world as substantively meaningful" (Sherratt, 2000: 34-35).

Hence, Habermas claims that, for Horkheimer and Adorno, the price of being enlightened is that of exploiting everything and being unable to cognize the world without utility. Further, the modern world is not fully divorced from mythical backgrounds, since as a project it can only be defined in its exclusion of the pre-modern. Emancipation and maturity come at the price of suppressing one's inclination towards experiencing the world. Hence; "the compulsion toward rational domination of externally impinging natural forces has set the subject upon the course of a formative process that heightens productive forces without limit for the sake of sheer self-preservation, but lets the forces of reconciliation that transcend more self-preservation atrophy" (Habermas, 1987: 110).

For Horkheimer and Adorno, humanity's attempts at survival led in the final stage to an instrumental rationality that damaged other ways of relating to the world of objects and other subjects, and managed to establish instrumental rationality as the only way of relating to the world. What's further expected of Horkheimer and Adorno, according to Habermas, is to show how this instrumental rationality managed to contaminate the modern value spheres of science, morality and law, and art. Here in relation to science, Horkheimer and Adorno are convinced that modern science's insistence on exclusively cognizing and theorizing that which is to be exploited and utilized, is best depicted in positivistic orientations to science. Instead of trying to conceptualize things generally in terms of "their social, historical and human significance", positivism aimed at pinning down the exact properties of things and entities, so that they can be utilized (Ibid., 111).

Horkheimer and Adorno extended their critique of positivism, to science in general, by claiming that all the sciences are arenas of instrumentality. Accordingly, "enlightenment behaves toward things as a dictator toward men. He knows them in so far as he can manipulate them. The man of science knows things in so far as he can make them. In this way, their potentiality is turned to his own ends" (Horkheimer \& Adorno, 1982: 9). Also, in relation to morality and law, Horkheimer and Adorno expressed their doubts toward a supreme authority that can be used as a criterion, emanating from either religion or pure reason itself, and instead focused on how relations of instrumentality and domination characterize the moral and legal spheres. Finally, art instead of trying to declare its autonomy and reflexivity towards other spheres, has on the contrary tried to imitate and ally itself with the truths of the instrumental sciences, law and morality. This is best depicted in mass culture which organizes the masses into a dominant ideological structure.

As such:

The culture industry perpetually cheats its consumers of what it perpetually promises. The promissory note which, with its plots and staging, it draws on pleasure is endlessly prolonged; the promise, which is actually all the spectacle consists of, is illusory: all it actually confirms is that the real point will never be reached, that the dinner must be satisfied with the menu (Horkheimer \& Adorno, 1982: 139). 
If this is true, then Habermas thinks that, the intersubjective communicative processes based on validity claims have been undermined. Weber's rationalization of the lifeworld and emergence of the three value spheres and the correlating validity claims in everyday world will all be undermined. Habermas admits that in modern capitalist societies the inclination towards minimizing all questions to issues of one's own interest and generally the interest to preserve oneself has increased. Still, the production of truth through distinct validity claims and the kind of "give and take" ethos between the three validity claims and the three value spheres haven't completely been undermined. Hence, "the dialectic of enlightenment does not do justice to the rational content of cultural modernity that was captured in bourgeois ideals (and also instrumentalized along with them)" (Habermas, 1987: 113). Habermas further asserts that, the rationality of modern sciences goes beyond the utilizable, and the universal basis of law and morality have been realized in various global, regional and national institutions and laws, and the reflexivity of modern art that take the subject beyond an instrumental rationality, all haven't been exhausted.

Habermas goes on to look at what animated Horkheimer and Adorno's critique of Enlightenment, and in relation to this, why they had to abandon Marx's critique of ideology. In mythical thinking and mythical societies, what is emphasized is how things stand in an intrinsic relation to the whole. Amongst other things, this excludes any division between one and others, and one and the objective world. In this context, "only demythologization dispels this enchantment... the process of enlightenment leads to the desocialization of nature and the denaturalization of the human world" (Ibid., 115). In "demythologization", the role of tradition is undermined, norms, conventions and rules are replaced by contestable claims to truth instead of a unitary whole, the world becomes differentiated into that of objects, norms and subjective, one. As Weber has shown, this "demythologization" results in the freeing of the lifeworld from the power of tradition, and in turn, the planting of different claims to truth, relating, to the objective, social and subjective worlds. So, where does the critique of ideology fit under this type of analysis?

As Habermas sees, it's only in the context of the rise of the value spheres of science, morality and laws and art replacing the power of traditions and myths, that one could make a critique of ideology, or question the extent to which the claims of the autonomous value spheres are contaminated by private or specific interests and agendas. Hence, "if one describes the process suspended between myth and enlightenment in this way, as the formation of a decentered understanding of the world, the place where the procedure of ideology critique enters into this drama can also be specified" (Ibid.). In the critique of ideology, the production of truth is seen in terms of the powers that influenced the production of the claims to truth. Thus, ideology critique tries to undermine the status of the so called value spheres, as being free of uncritical accounts and solely being based on the force of reason. Habermas marks, the ideology critiques or the questioning of the various spheres of the modern project as its moment of reflexivity or being aware of its own historical background and reflecting on this. This changes for Habermas, when reason itself is questioned or the issue whether reason itself can liberate humanity or when the aporia of what it means to reason are emphasized. But, what animated such a critique of reason itself? For Habermas, it's the frustration of Horkheimer and Adorno, in the failure of Marxist philosophy and its intentions. These include the inability of the masses to stage a revolution in the West, and the dominance of Stalinism and fascism, in soviet Russia and Germany respectively (Habermas, 1987: 116). Hence for Horkheimer and Adorno; "the impression could indeed get established in the darkest years of the second world war that the last sparks of reason were being extinguished from this reality and had left the ruins of a civilization in collapse without any hope" (Ibid., 117).

Initially, Horkheimer and Adorno took on Marx's critique of ideology with their insight that philosophy usually ends up affirming the status quo and that it's not equipped with the necessary tools to revolutionize existing states of affairs. So, from Marx, Horkheimer and Adorno 
took the insight that the dominant ideas, institutions and frameworks are those of the powerful social class and that critique should be aimed at exposing how so-called "emancipatory" theories and structures that supposedly stand for the whole society, in practice only serve the privileged few. This Marxian orientation guided the Frankfurt school's critical social theory's interdisciplinary approach to society in the 1930s. But in the 1940s, this critique of society, turned from what reason serves in society, to what reason has led humanity to in general, Hence, Horkheimer and Adorno "pushed for a radicalization and self-over-coming of ideology critique, which was supposed to enlighten the Enlightenment about itself" (Ibid., 118).

Horkheimer and Adorno, abandoned Marx's critique of ideology, since it was able to unravel not the destructive path that reason itself has led humanity into in its attempt to dismantle irrationality, but, how reason is directed by specific values and interests in a particular context. So, Horkheimer and Adorno moved to Nietzsche's critique of reason. Habermas sees the position of Horkheimer and Adorno towards Nietzsche's "will to power" and his critique of reason, as being "ambivalent", they accepted Nietzsche's general critique of reason, and reason's fusion with domination and resulting in instrumentality. Still this proved problematic since, if all reason is repression then what about the reason of critical social theory? So, Horkheimer and Adorno were trying to find a space within which their critical, reflective and emancipative reason towards society can be justified (Ibid., 120). One of the areas where there is a strong relation between Horkheimer and Adorno, and Nietzsche is in relation to the development of subjectivity. According to Nietzsche, the development of "consciousness" coincided with the suppression of basic human instincts being expressed in the form of will to power. For Horkheimer and Adorno, the modern subject is the one that has suppressed its "id" in favor of "ego" in Freud's terms. As Freud has it, in modern subjectivity, the id's inclination to "experience objects as pleasurable and also, importantly, as meaningful" (Sherratt, 2000: 532) has been suppressed by the ego's drive to preserve the self by exerting control, and instrumentally manipulate things.

Further, Nietzsche, Adorno and Horkheimer, share the idea that behind the modern sciences, morality and religion, lies humanity's urge to preserve itself, and the manifestation of humanity's endless drive towards the world, manifesting itself in an instrumental relation to the world (Habermas, 1987: 122). Habermas claims that in Nietzsche, notions like the contestation of validity claims, and generally truth, are abandoned to that of the "will to power" and the ability to impose meaning. Nietzsche expounds his analysis of the will to power and its degeneration into ascetic ideals in his Genealogy of Morals. In this work, Nietzsche tried to make a historical analysis of different conceptions of the moral. He further claimed that the development of different civilization and their moral conceptions is related to a unique class of society which establishes its hegemony, affirms life, and conquers the environment making itself the source of moral values. In his survey of the cultural history of humanity, Nietzsche identified two major types of morality, i.e. "master" and "slave". "Master" morality is characterized by moral agents who know they are the "measures" of things, they affirm their biological instincts for power and thereby impose meaning on things. On the contrary, we find in "slave" morality one which is populated by individuals who have no respect for life, strife, struggle and competition. So, with his genealogy; "Nietzsche has in hand the conceptual means by which he can denounce the prevalence of the belief in reason and of the ascetic ideal, of science and of morality, as a merely factual victory (though of course decisive for the fate of modernity) of lower and reactionary forces" (Ibid., 126).

\section{Communicative rationality as the "unpursued" path in modernity}

For Habermas one common way of justifying the sciences is to see them as the logical implications of the subject's reflection. Thus, the sciences are understood as the results of the subject's attempt to understand itself and the world. Still this has resulted in the long run in "scientism"; the idea that the natural sciences provide the only available route to knowledge. Foucault rightly asserted this for Habermas. Still, he did not adequately address the extent to 
which his own genealogy detaches itself from the other sciences and there by succeeds in establishing its status as a value free unmasking methodology. In the final analysis, Foucault's genealogy for Habermas turns out to be everything that it has criticized of the various sciences. Hence: "presentism, relativism, and cryptonormativsm are the consequences of his attempt to preserve the transcendental moment proper to generative performances in the basic concept of power while driving from it every trace of subjectivity. This concept of power does not free the genealogist from contradictory self- thematizations" (Ibid., 294-95).

As an alternative, Habermas proposes a new reading, a new critique of the human sciences and of reason that would go beyond the aporias faced by the radical critics of modernity from Nietzsche, passing down to poststructuralism. The radical critics of modernity failed to recognize that there was a possibility of another critique of subjectivity and hence an alternative to it, within the philosophical discourse of modernity. From the young Hegelians, Nietzsche, all the way up to poststructuralism, there was an alternative of a communicative rationality which was not pursued, and Habermas tries to reconstruct this path. Thus he remarks, "it behooves us to retrace the path of the philosophical discourse of modernity back to its starting point- in order to examine once again the directions once suggested at the chief crossroads. This is the intention behind these lectures" (Ibid., 295).

Hegel and Marx try to step outside of the confines of the philosophy of the subject by envisaging an ideal where under the state or communism, citizens will become equal, free, and realize their potentials, cooperating with one another. Heidegger and Derrida should have avoided appealing to ontico-ontological significance of a being that can give an insight to Being itself as such, and a heterogeneous state determining all meaning. Instead they should have resorted to the communicative paradigm. In Heidegger, Dasein has a unique place as a being that interrogates Being as such, and thus was taken as a point of departure. Habermas urges the interlocutors in the philosophical discourse of modernity to abandon the subject-object metaphysics, where the subject is oriented towards an objective possible state of affairs, and instead tries to strengthen the communicative action taking place between individuals in modern societies. Hence, he remarks, "I have already suggested that the paradigm of the knowledge of objects has to be replaced by the paradigm of mutual understanding between subjects capable of speech and action" (Ibid., 295-296).

Habermas sees in Heidegger, Derrida and Foucault a rejection of the subject that establishes its primacy by its reflection on the world. But, whereas Heidegger and Derrida tried to make some compromise, by establishing the Dasein Analytic, and show how the subject participates in a Heterogeneous deferred meaning formation; Foucault on the contrary tried to completely denounce the subject in placing it under concrete, material, and specific power/knowledge relationships. From Habermas's point of view, the divisions between empirical and transcendental, Being and beings, noumenal and phenomenal, all point to the fact that, the reason of the modern project is 'exhausted'. All these distinctions are attempts to preserve the philosophy of the subject under different formulations. Some situated the subject as locus of possible cognition. Others show that the subject is completely autonomous, while there are also some that place the subject under different repressive relations. But all these are exhausted for Habermas since no attempts have been successful to come up with a strong alternative. The solution is making the move to communicative rationality and intersubjectivity. Hence Habermas remarks that, "[t]he paradigm of the philosophy of consciousness is exhausted. If this is so, the symptoms of exhaustion should dissolve with the transition to the paradigm of mutual understanding" (Ibid., 296).

Habermas summarizes most of the ideas raised in his The Philosophical Discourse of Modernity, in a chapter Conceptions on Modernity: A look back at two traditions; in a later work entitled The Postnational Constellation, Political Essays. In this chapter, Habermas tries to show 
why the discussion of modernity was clearly articulated in philosophical circles, by trying to address three major issues. These are:

(1) When, and why, did philosophers become interested in the interpretation of the specific condition of modernity? (2) Why do these philosophical interpretations take the form of a critique of reason? (3) Why did philosophy ultimately cede the ongoing task of an interpretation of modernity to social theory? (Habermas, 2001: 130-31).

Chronologically speaking, Habermas dates the use of the word modern to "late fifth century", where Christianity tried to distinguish itself from the "pagan Roman past" (Ibid., 131). What especially interests Habermas is how the term modern subsequently comes to signify the notion of a present and supposedly radical moment which tries to detach itself from the alleged backward and unenlightened state of the past. Further, the establishment of the uniqueness of the present was to be affirmed by seeking an enlightened, glorious moment to be pursued. This is seen in how the renaissance tries to appeal to the glorious moment of enlightened Greece, and hence detaches itself from the past. Habermas further notes that "around 1800" a consciousness of modern time began to emerge, which instead of trying to appeal to a glorious past, divided history into ancient, medieval and modern, and then tried to establish the present as the modern which surpasses the darkness of the medieval stage.

In the aesthetic quarrel between the protagonists of modern and ancient art, the issue of modernity was further articulated. Its only at the beginning of the nineteenth century that philosophy tried to conceptualize the modern, as its subject of thought, as such. This is signified in Hegel's philosophy that located the modern, in terms of how the present moment is clearly established in the great achievements in history like the French revolution that stood contrarily to medieval past and also the idea of a novel stage in human history where all contradictions were to be resolved. Accordingly; "history is now experienced as an all encompassing, problem generating process, and time as a scarce resource for mastering the problems that the future hurls at the present this head long rush of challenge is perceived as the "pressure of time" (Ibid., 132).

Concerning the second issue, one of the problems modernity was faced with, was evolving its own criteria of right and wrong. Since modernity equated the medieval age to blind submissions to authority and tradition, it equates its vision with those of reason. Philosophy was particularly trying to articulate where the progress of humans by the power of reason was going and should go. Habermas claims, "as the custodian of reason, philosophy conceives modernity as a child of the enlightenment" (Ibid., 133). Finally, for Habermas, Max Weber traces the origin of modern society to a process where traditions of authority and religion were replaced by a culture that solved basic issues by a reason divided into the "value spheres" of science, morality, and art. But for Weber, this process soon resulted in an instrumental rationality under the apparatus of "state and economy". While the state institutes a system where individuals are grouped under their specific tasks, the economy utilizes this specified labor under different forms of productive processes in the capitalist era. In this scenario, the only emancipatory ideal was held to be, "the strong, self-reliant subject.., in lucky instances, succeed in forming a coherent life project of its own, in opposition to a rationalized, and fragmented society" (Ibid., 140).

Weber's themes of the subordination of individuals under larger structures of repression was to be further developed by Horkheimer and Adorno amongst others, who portrayed a society trapped by instrumental rationality and how reason which is the only emancipatory ideal proved difficult in the final analysis. The instrumental rationality functioned through the various sciences, arts, morals, laws, entertainment, and so on, to create a society full of conformists. Out of this aporia, the critique of modernity comes to the point that, it has to give up either the empirical analysis exposing how the modern project practically functioned, or the theoretical critique of reason, equating reasoning with instrumentality as such. Hence, "[t]he end of the cooperative division of labor between philosophy and social theory means uncoupling a criticized 
self-understanding of modernity from an empirical observation and descriptive account of its tendencies to social critics" (Ibid., 142).

Weber's empirical explanations of a society trapped under an instrumental rationality, were divided into and hence further developed by, "rational choice theory" which characterizes modern individuals as employing strategic actions aimed at achieving individualistic interests, and "systems theory" portraying how various structures functioned to dictate individuals (Ibid., 142). In philosophical circles, in Heidegger and Wittgenstein, "reason is equated with operation of an objectifying and manipulating understanding with "representational thinking" and philosophical abstraction with the controlling power and discipline of self-maintaining, narcissistically selfassertive subjectivity" (Ibid., 143).

The ideas of Heidegger and Wittgenstein are being echoed in postmodernist attempts at a critique of modernity. Habermas summarizes his critique of postmodernism by claiming that its critique of reason and specifically modern reason as anarchistic and repressive representing hidden intentions and motives is too exaggerated to the extent of not being able to recognize the positive sides of the Enlightenment. Further, even to assert that there are diverse rationalities embedded in particular contexts the postmodernist needs to go beyond relativism and assert that reason is universally embedded in various contexts. Hence, "to interrupt its own self preferentiality, a relativistic position must make an exception of the stated principle of incommensurability, precisely in the performative act of asserting it" (Ibid., 150). Habermas in turn, proposes his communicative rationality that looks at everyday practice, communicative action, and tries to identify what made this communication possible, at what background it's being conducted, and how it furnishes a theory of rationality based on the raising and contestation of various claims to truth.

\section{Modernity and the aesthetic}

Having considered Habermas' critique of Horkheimer and Adorno, let's try to analyze the place of the aesthetic in his discourse. In most philosophical orientations, the aesthetic is usually reduced to either a fancy contemplation raising issues that have no real value, or a dangerous realm that could damage discussions of knowledge or social and political thought. What is the role of the aesthetic in Habermas's discourse of modernity? Here, I will use David Ingram's essay Habermas on Aesthetics and Rationality, Completing the Project of Enlightenment, to point out some of the difficulties found in Habermas's views on the aesthetic. As Ingram sees it, compared to the works of other members of the Frankfurt school of critical theory, Habermas hasn't made the aesthetic a crucial aspect of his theories on modern society. Habermas acknowledged the aesthetic as hosting a distinctive form of rationality within the general rationalization of the lifeworld.

For Ingram, at the heart of Habermas' discussions of the aesthetics, is found the division of four periods through which modern art developed. First, in the "Renaissance", art and the aesthetic become separated from tradition, and religious authority. Secondly, towards the end of the $18^{\text {th }}$ century, art was to become embodied in certain institutions like "museums" and practices like "theatres". Thirdly, in "late romanticism" art become highly divorced from moral, cognitive, political and other spheres. Finally, art became disseminated through "introduction of dynamic mechanisms of artistic reproduction such as film, radio and television" (Ingram, 1991: 70). Generally, what one witnesses in modern art, for Habermas is how art has become freed from conventional religious authority and was established as a sphere where aesthetic issues were debated. To this extent, it has become "worldly". But, because of movements stressing the intrinsic worth of art and its separation from theoretic practical affairs, modern art also has a 'transcendent' facet (Ibid., 71). The attempt to free art from ideological interests and establish its status as a separate domain led to art being more and more divorced from everyday life. 
For Habermas, both art for art's sake and art as a way of effecting instrumentality are results of the colonization of the lifeworld. The former being an attempt to free art of any interests and herald its genuinity, while the latter shows how art has been ideologically manipulated. As a solution, Habermas locates aesthetic rationality, as one of the validity claims raised in every communicative interaction, which is "an expressive claim to truthfulness" (Ibid., 78). Still, Habermas maintains that subjective claims to truthfulness does not sufficiently lead to areas of inquiries or concrete structures providing stocks of materials and also doesn't have a strong capacity for solving society's problems as the claims to truth and rightness does. This for Ingram, "[d]eprives society of perhaps the only medium capable of communicating aesthetic discoveries gained in rational discourse to social agents engaged in every day moral/conversation" (Ibid., 79). Habermas also needs to explain how the act of expressing one's subjective claims is related to art. Further, in every day communication we usually act in order to accomplish our own goals, and the extent to which our subjective claims could be universalizable is questionable.

As Ingram sees it in Habermas' works like What is Universal Pragmatics, there was no distinction between poetic language and every day normal language, and it was debatable whether the three distinct validity claims are found in both kinds of language. Acknowledging this, Habermas for Ingram, tried to incorporate three new ideas in his theory. These include, first, arguing that language's function also includes "a poetic disclosure of the world". Secondly holding that validity also includes "non pragmatic expressive and evaluative claims". Thirdly, developing an idea of aesthetic critique "that deviates in important respect from the standard model of argumentative rationality" (Ibid., 80). Habermas argues that while artistic and poetic uses of language also operate in everyday language, the main goal of interlocutors is to communicate by raising distinct claims to truth. Poetic usages of Language are taken out from normal usages of language, and are employed in such a way as to pose new ideals and perspectives. Still, poetic language is "parasitic" and reducible to the normal usage. Habermas also argued that the poetic function gains its status in its ability to pose new alternatives. This is the extent to which this perspective has an ability to go beyond the situation in which it was articulated. In other words, its degree of "worthiness", needs to be taken into account (Ibid., 82; Habermas, 1987: 203). This clearly shows that Habermas wants the aesthetic to be rational or that which can be contested. Habermas admitted that the poetic function gazes at the whole, but still this experience is subordinated and reducible to everyday normal language.

What we can learn from Ingram's insights into Habermas's view of the aesthetic is that Habermas continually tries to restrict the aesthetic experience by, subordinating the poetic function of language to the normal one. Habermas also argues that even though the aesthetic gazes at the whole this is limited compared to the rationality of other validity claims. Because the poetic function is derivative, the ideals it poses are continually subjected to the rationality of the validity claims. The aesthetic which usually excites the passions of individuals is subordinated to an argumentative rationality. Also, Habermas did not realize that the poetic function offers a critique that usually appeals to passions and emotions, and posits ideals that revolutionize existing affairs. Hence the poetic function goes beyond the normal usage of language in its ability to grasp the whole at once, whereas the validity claims are oriented towards only one aspect of reality at a time. Also making the aesthetic disputational, disempowers the power of art to incite passions and emotions and pose radical ideas.

\section{Conclusion}

As Habermas sees it, inheriting Nietzsche's will to power and the totalized critique of reason, Horkheimer and Adorno depicted a world where an individual is trapped in instrumentality. Such form of critique transitions from a Marxian critique of ideology to a Nietszschean critique of reason. Here the dilemma lies in reason being the only tool of critique, but still ending up being instrumental. Although Habermas rightfully identified the limitations of 
such a project, his linguistic alternative exhibits a tendency to marginalize the aesthetic for the discursive and thereby situating the aesthetic on the poetic function of language which is suppressed in everyday discourse.

\section{Acknowledgements}

This research did not receive any specific grant from funding agencies in the public commercial, or not-for-profit sectors.

The author declares no competing interests.

\section{References}

Dallmayr, F. (1987). The discourse of modernity, Hegel and Habermas. The Journal of Philosophy, vol. 84.

Habermas, J. (1987). The philosophical discourse of modernity, Twelve Lectures, Massachusetts Institute of Technology. Cambridge, Massachusetts.

Habermas, J. (2001). The postnational constellation, Political essays. Cambridge, Massachusetts: MIT Press.

Horkheimer, M. \& Adorno, Th. (1972). The dialectic of enlightenment. New York: Seabury.

Ingram, D. (1991). Habermas on aesthetics and rationality completing the project of enlightenment. New German Critique, 53, 67-103.

Love, N. S. (1986). Marx, Nietzsche and modernity. New York: Colombia University press.

Melchert, N. (2002). The great conversation, A historical introduction to philosophy, Fourth Edition. The McGraw Hill Companies, U.S.A.

Sheratt, Y. (2000). Adorno and Horkheimer's concept of enlightenment. British Journal for the History of Philosophy, 8(3), 521-544. https://idx.doi.org/10-1080/096087800442165 